\title{
Konteks Pencak Silat pada Soal Matematika Tipe PISA
}

\author{
Harisman Nizar \\ Program Studi Pendidikan Matematika, Fakultas Ilmu Tarbiyah dan Keguruan, UIN Raden Fatah Palembang, \\ J1. Prof. K.H. Zainal Abidin Fikri KM. 3,5, Palembang, Indonesia \\ harismannizar_uin@radenfatah.ac.id
}

\begin{abstract}
The purpose of this study was to produce valid and practical PISA-like mathematics problems and have a potential effect on mathematical literacy skills using the Pencak Silat Context. The research subjects were students of class X SMA. The methodology in this research is design research with the type of development study, with 2 stages, namely preliminary and formative evaluation stages. At the formative evaluation stage, it includes one-to-one, expert review, small group, and field test. Data collection techniques used are observation, walkthrough, documents, interviews, and test. The research conducted produces valid and practical questions and has a potential effect on mathematical literacy skills. Validity can be seen from the results of expert assessments that review in terms of content, constructs, and language as well as student work at the one-to-one stage. Practically, it can be seen from the work of the small group stage students can understand the meaning or language of the questions. Then from the students' answers at the field test stage, the questions have a potential effect, namely bringing up representation ability and the ability to use language and symbolic, formal, and technical operations.
\end{abstract}

Keywords: PISA-Like Mathematics Problem, Pencak Silat, Mathematical Literacy

\begin{abstract}
Abstrak
Tujuan dari penelitian ini yaitu untuk menghasilkan soal matematika tipe PISA yang valid dan praktis, serta memiliki efek potensial terhadap kemampuan literasi matematis dengan menggunakan Konteks Pencak Silat. Subjek penelitian adalah siswa kelas X SMA. Metodologi pada penelitian ini yaitu design research dengan tipe development study, dengan 2 tahap yaitu preliminary dan tahap formative evaluation. Pada tahap formative evaluation meliputi one-to-one, expert review, small group, dan field test. Teknik pengumpulan data yang digunakan adalah observasi, walkthrough, dokumen, wawancara, dan tes. Penelitian yang dilakukan menghasilkan soal yang valid dan praktis serta memiliki efek potensial terhadap kemampuan literasi matematis. Valid terlihat dari hasil penilaian expert yang mereview dari segi konten, konstruk, dan bahasa serta pengerjaan siswa pada tahap one-to-one. Praktis terlihat dari pengerjaan siswa tahap small group yang siswa dapat memahami maksud atau bahasa soal. Kemudian dari jawaban siswa pada tahap field test soal memiliki efek potensial yaitu memunculkan kemampuan representasi dan kemampuan menggunakan bahasa dan operasi simbolis, formal dan teknis.
\end{abstract}

Kata kunci: Soal Matematika Tipe PISA, Pencak Silat, Literasi Matematis

Copyright (c) 2021 Harisman Nizar

$\bowtie$ Corresponding author: Harisman Nizar

Email Address: harismannizar_uin@radenfatah.ac.id (Jl. Prof. K.H. Zainal Abidin Fikri, Palembang, Indonesia) Received 10 August 2021, Accepted 27 August 2021, Published 28 August 2021

\section{PENDAHULUAN}

PISA adalah studi internasional untuk mengetahui kemampuan literasi siswa usia 15 tahun termasuk Indonesia (OECD, 2019). Siswa Indonesia masih lemah ketika mengerjakan soal PISA baik pada ranah literasi matematika, sains, membaca, maupun keuangan. Hasil siswa Indonesia dalam mengerajakan soal PISA matematika 3 periode menunjukkan pada peringkat bawah. Hasil PISA matematika tahun 2018 Indonesia berada pada peringkat 62 dari 70 negara. Penyebab dari hal karena siswa belum terbiasa mengerjakan soal yang mengandung penalaran dan level tinggi serta lemah dalam kemampuan literasi matematika (Novita et al., 2012; Stacey, 2010; Wu, 2011).

Pada abad ke 21 Kemampuan literasi matematika sangat penting bagi siswa untuk mempermudah menyelesaikan soal matematika (Astuti, 2018; Hasanah et al., 2016). Literasi matematika membuat 
siswa dapat memecahkan masalah, berpikir kritis dan bernalar sehingga dapat menyelesaikan permasalahan yang kompleks dalam kehidupan sehari-hari. Dengan literasi matematika yang baik dapat meningkatkan SDM yang berkualitas (Hasanah et al., 2016). Dengan literasi matematika yang baik maka siswa Indonesia dapat bersaing di era globalisasi abad ke 21 ini.

Pencak silat merupakan olahraga bela diri yang berasal dari Indonesia yang dapat dimainkan secara beregu ataupun individu (Muhajir, 2016). Di dalam pencak silat terdapat bagian-bagian untuk pembelaan diri. Konteks olahraga dapat digunakan dalam mengembangkan soal matematika tipe PISA(Jannah et al., 2019; Yansen et al., 2019). Penggunaan konteks sangat penting karena dapat memudahkan siswa ketika mempelajari matematika. Hal ini dikarenakan dengan menggunakan konteks dapat memotivasi siswa dalam belajar matematika (Nizar et al., 2018a, 2018b; Widjaja, 2013). Konteks Pencak Silat dekat dengan siswa karena diseluruh Nusantara sudah mengenal pencak silat dari zaman dahulu sampai sekarang.

Penelitian sebelumnya yang relevan dalam mengembangkan soal matematika tipe PISA dengan berbagai fokus seperti mengembangkan soal PISA menggunakan Konteks Sepak Bola dan Tenis Meja yang dilakukan oleh (Nizar et al., 2018a). Kemudian penelitian oleh (Maharani et al., 2019) yang mengembangkan soal matematika tipe PISA dengan Konteks Akuatik. Kemudian penelitian oleh (Dasaprawira et al., 2019) yang mengembangkan soal matematika tipe PISA dengan Konteks Bangka. Kemudian penelitian oleh (Andita et al., 2020) yang menggunakan Konteks Covid-19 dalam mengembangkan soal matematika tipe PISA. Hal ini menunjukkan bahwa banyak peneliti yang tertarik dan menganggap penting untuk dikembangankannya soal matematika tipe PISA karena merupakan kebutuhan siswa untuk mengenal soal-soal matematika PISA sehingga siswa terlatih dalam mengerjakan soal matematika PISA. Selain itu (Zulkardi, 2010) menyarankan untuk mengembangkan soal matematika tipe PISA. Berdasarkan uraian tersebut, perlunya dikembangkan soal matematika tipe PISA dengan menggunakan konteks pencak silat.

\section{METODE}

Metode yang digunakan adalah metode penelitian design research dengan tipe development studies. Penelitian ini terdiri dari dua tahap yaitu preliminary dan tahap formative evaluation yang meliputi self evaluation, expert reviews dan one-to-one, small group, serta field test (Tessmer, 1993; Zulkardi, 2006). Subjek penelitian yaitu siswa kelas X SMA di Palembang yang berumur 15 tahun.

Pada tahap preliminary, peneliti menentukan tempat dan subjek penelitian, menghubungi pihak sekolah, menganalisis kurikulum 2013. Selain itu peneliti mendesain instrumen soal. Pada tahap formative evaluation yang dilakukan pertama kali yaitu self evaluation. Self evaluation peneliti menelaah dan mengevaluasi prototype awal. Hasil tersebut dianalisis sehingga terbentuk prototype 1.

Tahap berikutnya yaitu expert reviews. Pada tahap ini prototype 1 divalidasi oleh expert dengan cara dievaluasi, ditelaah, dan dinilai dari segi konten, konstruk, dan bahasa. Proses validasi tahap expert reviews dengan 2 cara, yaitu dengan mengirim e-mail kepada Validator 1 dan 2 dan langsung tatap muka 
dengan Validator 3. Hasil dari tahap expert reviews digunakan untuk melakukan revisi prototype 1.

Peneliti melakukan uji kepada siswa secara individu (one-to-one) bersamaan dengan expert reviews. Pada one-to-one prototype 1 diujikan kepada 3 siswa yaitu 1 siswa kemampuan tinggi, 1 siswa kemampuan sedang, 1 siswa kemampuan rendah. Fokus pada one-to-one yaitu untuk melihat kejelasan/keterbacaan soal. Hasil dari one-to-one digunakan untuk merevisi prototype 1 yang dibuat. Didapatkan prototype 2 yang telah valid setelah revisi dari tahap expert reviews, dan one-to-one.

Pada tahap small group prototype 2 diujicobakan kepada 6 orang siswa yaitu 2 siswa dengan kemampuan tinggi, 2 siswa dengan kemampuan sedang, dan 2 siswa dengan kemampuan rendah. Kepraktisan soal diketahui pada tahap small group. Hasil dari tahap small group bernama prototype 3 yang telah praktis.

Pada terakhir yaitu tahap field test, prototype 3 yang didapatkan setelah tahap small group diteskan kepada satu kelas yang terdiri dari 33 siswa. Tahap field test ditujukan untuk mengetahui efek potensial soal terhadap kemampuan literasi matematis siswa. Untuk mengetahui kemampuan literasi matematis yang muncul yaitu dengan menganalisis jawaban siswa berdasarkan proses pada soal (apakah formulasi, penerapan, atau interpretasi) kemudian melihat indikator dan deskriptor dari kemampuan literasi matematika berdasarkan framework PISA yang muncul.

\section{HASIL DAN DISKUSI}

\section{Tahap Preliminary}

Pada tahap preliminary peneliti menentukan tempat penelitian yaitu SMA di Palembang dan subjek penelitian yaitu siswa kelas X yang berumur 15 tahun. Kemudian menghubungi pihak sekolah yaitu wakil kurikulum dan guru mata pelajaran matematika untuk menanyakan prosedur dan jadwal penelitian di sekolah tersebut. Kemudian peneliti menganalisis framework PISA dan soal - soal matematika tipe PISA yang sudah ada, serta. Selanjutnya peneliti mengembangkan soal berdasarkan soal matematika PISA yang sudah ada. Peneliti mengembangkan instrumen soal menggunakan konteks pencak silat yang terdiri dari kartu soal, kisi-kisi soal, dan rubrik penskoran. Berikut penjelasan soal tersebut pada tahap preliminary.

Peneliti mengembangkan soal PISA dari soal PISA sebelumnya yaitu pada tahun 2006 yaitu “Tennis Tournament”. Soal Tennis Tournament ini meminta siswa menyusun jadwal pertandingan turnamen tenis dari 4 pemain tenis dengan menuliskan nama-nama pemain di setiap pertandingan pada tabel yang telah disediakan dengan syarat setiap pemain tenis bertanding satu kali dengan pemain tenis yang lain. Soal PISA yang dikembangkan adalah "Latihan Pencak Silat". Pada soal meminta siswa menyusun jadwal latihan silat dari 6 pesilat dengan menuliskan nama-nama pemain di setiap rondenya. Adapun tempat latihan yang tersedia adalah tiga tempat dengan syarat setiap pesilat bertanding satu kali dengan pesilat lainnya. Menyelesaikan permasalahannya dengan menggunakan konsep ruang sampel dengan menyusun jadwal pesilat yang bertanding dan memperhatikan syarat setiap pesilat bertanding satu kali dengan pesilat lainnya. Pada soal tersebut menggunakan konteks sosial, konten uncertainty and 
data, dan prediksi level soal matematika PISAnya yaitu level 3.

Tabel 1. Pengembangan Soal

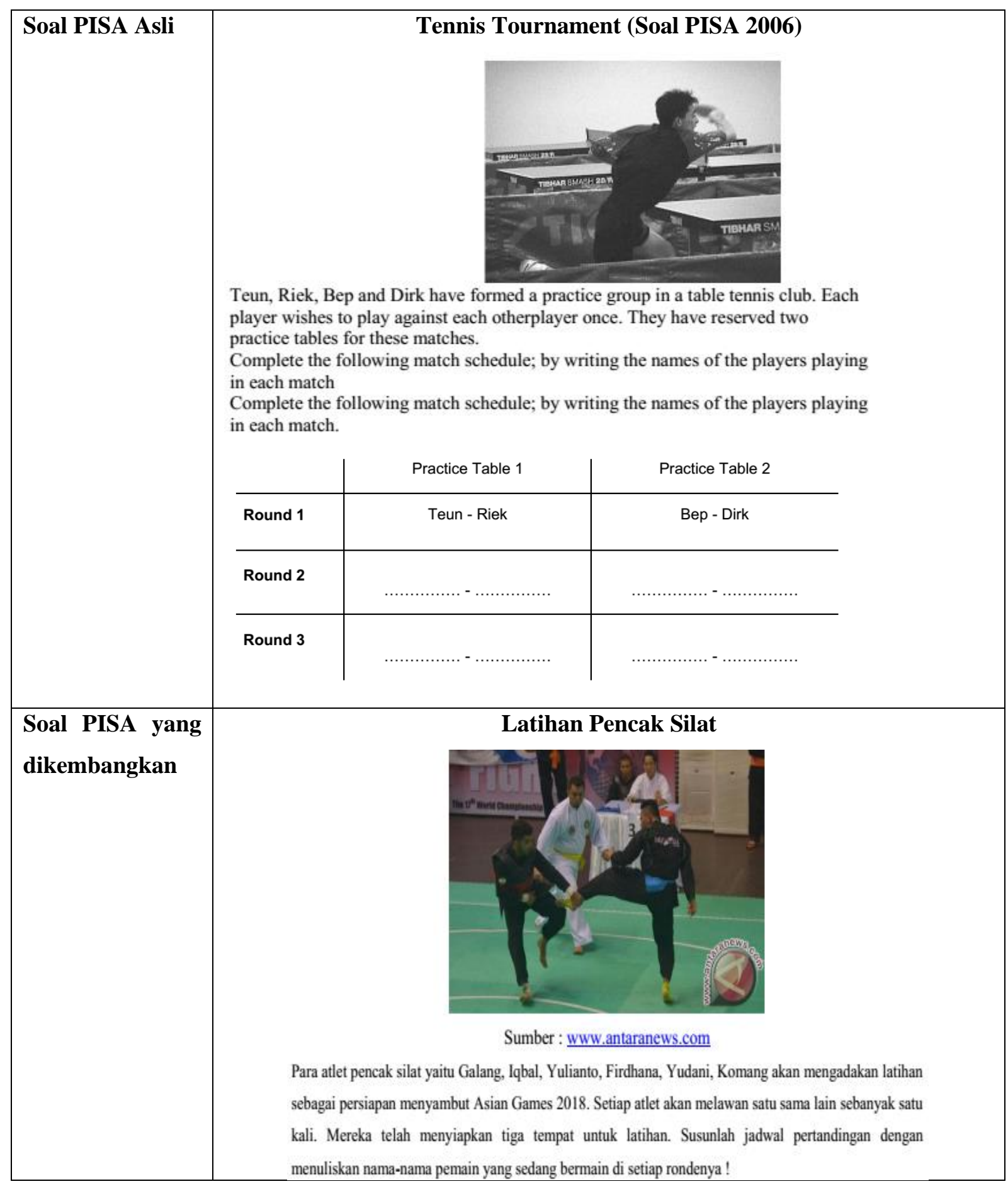

\section{Self Evaluation}

Tahap self evaluation yang dilakukan peneliti yaitu menalaah dan mengevaluasi dan menelaah prototype 0 yang sebelumnya telah dibuat ketika tahap preliminary berdasarkan dari 3 karakteristik yaitu ranah konten (materi), konstruk, dan bahasa. Karakteristik tersebut divalidasi sendiri oleh peneliti dan dengan rekan sejawat. Prototype 1 adalah hasil dari tahapan ini. 


\section{Expert Reviews dan One-to-One}

Yang dilakukan peneliti pada expert reviews yaitu memberikan soal kepada validator untuk divalidasi dari ranah konten, konstruk, dan bahasa. Adapun yang menjadi validator yaitu 3 orang yang ahli mengenai soal matematika PISA.

Bersamaan dengan tahap expert reviews soal diuji cobakan pada tahap one-to-one. Yang dilakukan peneliti di tahap one-to-one, soal prototype pertama diujikan kepada siswa yang jumlahnya adalah 3 orang. Siswa-siswa tersebut mengerjakan soal kemudian setiap siswa memberikan komentar, saran, dan pendapatnya. Pada tahap one-to-one peneliti mengamati kejelasan dan keterbacaan soal, serta respon siswa dalam mengerjakan soal. Berikut komentar / saran dari expert dan siswa serta keputusan revisi pada soal pada tabel 2 .

Tabel 2. Saran/Komentar dari Expert dan Siswa pada Soal

\begin{tabular}{|l|l|l|}
\hline Validasi & Saran / Komentar & Revisi \\
\hline Validator 1 & $\begin{array}{l}\text { Tambahkan keterangan setiap tempat harus } \\
\text { terisi pemain disetiap rondenya }\end{array}$ & $\begin{array}{l}\text { Menambahkan keterangan } \\
\text { "setiap tempat harus terisi nama } \\
\text { pemain". }\end{array}$ \\
\cline { 1 - 2 } Validator 2 & Soal diterima & \\
\hline Validator 3 & Soal diterima & $\begin{array}{l}\text { Kata-kata pada soal mudah dipahami namun } \\
\text { sebaiknya soal ditambahkan kata-kata "semua } \\
\text { tempat harus selalu terisi dan pertandingan } \\
\text { dengan ronde sesedikit mungkin" }\end{array}$ \\
\cline { 1 - 2 } Siswa 1 & $\begin{array}{l}\text { Masih bingung kata-kata pada soal yaitu kata- } \\
\text { kata "mereka telah menyiapkan 3 tempat } \\
\text { untuk latihan" }\end{array}$ \\
\cline { 1 - 2 } Siswa 2 & $\begin{array}{l}\text { Masih bingung kata-kata pada soal yaitu kata- } \\
\text { kata "mereka telah menyiapkan 3 tempat } \\
\text { untuk latihan" }\end{array}$ \\
\hline Siswa 3 & \multicolumn{2}{|l|}{} \\
\hline
\end{tabular}

Berdasarkan saran/komentar dari tahapan expert reviews, serta one-to-one soal direvisi sehingga menjadi prototype kedua yang telah valid. Kevalidan terlihat dari hasil penilaian expert terhadap soal dari ranah konten, konstruk dan bahasa pada tahap expert reviews, selain itu dari saran/komentar siswa pada langkah one-to-one terhadap keterbacaan/kejelasan dari soal yang dikembangkan.

\section{Small Group}

Pada tahap small group soal peneliti membagi dua kelompok siswa yang berjumlah 6 orang, sehingga setiap kelompok berjumlah 3 orang. Ketiga orang dalam kelompok tersebut memiliki kemampuan matematika yang berbeda. Berikut komentar dan hasil pengerjaan siswa pada tabel 3.

Tabel 3. Komentar dan Hasil Pengerjaan Siswa

\begin{tabular}{|c|c|}
\hline Kelompok 1 & Kelompok 2 \\
\hline $\begin{array}{l}\text { 1. Memahami maksud soal } \\
\text { 2. Menjawab dengan benar } \\
\text { 3. Memberikan alasan atau bukti } \\
\text { secara lengkap }\end{array}$ & $\begin{array}{l}\text { 1. Memahami maksud soal } \\
\text { 2. Memberikan alasan dengan bukti yang } \\
\text { kurang lengkap }\end{array}$ \\
\hline
\end{tabular}


Berdasarkan tahap small group ke enam siswa yang telah dibagi menjadi 2 kelompok sudah mengerti pertanyaan maupun petunjuk yang terdapat pada soal, memahami soal, sebagian besar tidak menemui kesulitan ketika menjawab soal, sebagian besar sudah dapat menjawab dengan benar soal. Kepraktisan terlihat dari kemudahan siswa dalam memahami soal (Riyanto et al., 2018). Prototype 3 kemudian diuji cobakan pada tahap field test. Berikut prototype 3 soal pada gambar 1.

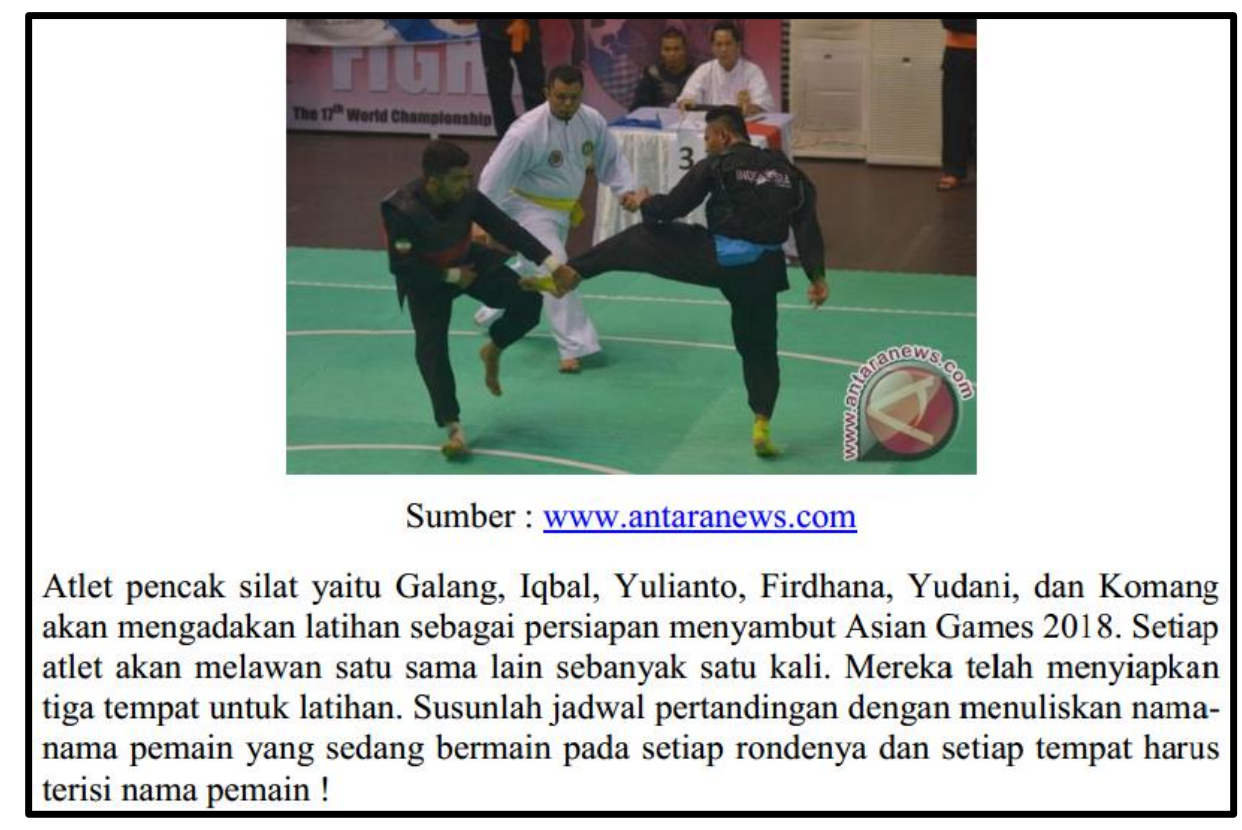

Gambar 1. Prototype 3

\section{Field Test}

Prototype 3 diuji cobakan kepada satu kelas yaitu siswa kelas X dengan jumlah siswa yaitu adalah 33 orang. Pada fase ini seluruh siswa mengerjakan prototype 3. Adapun fokus dari tahap ini yaitu untuk mengetahui efek potensial dari soal. Ada beberapa strategi yang digunakan oleh siswa dalam menjawab permasalahan. Berikut beberapa strategi jawaban dari hasil pengerjaan siswa yaitu.

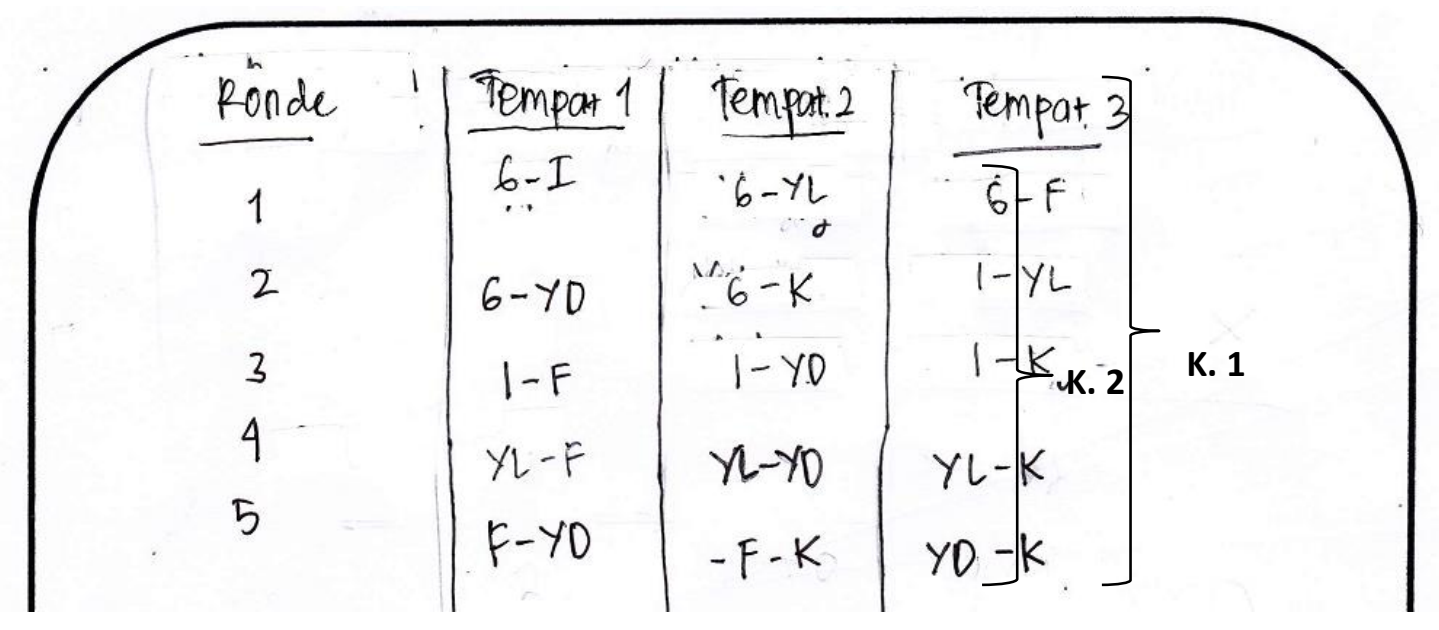

Gambar 2. Jawaban Siswa Strategi 1

Berdasarkan gambar 2. Dapat dilihat siswa membuat tabel untuk menyusun nama - nama pesilat 
yang akan berlatih hal ini menunjukkan bahwa strategi jawaban siswa memunculkan kemampuan representasi (K. 1), dan kemampuan menggunakan bahasa dan operasi simbolis, formal dan teknis (K. 2). Adapun penjelasan deskriptor pada kemampuan tersebut dapat dilihat pada tabel 4 .

Tabel 4. Kemampuan yang Muncul

\begin{tabular}{|l|l|l|}
\hline Kemampuan & Deskriptor & Jawaban Siswa \\
\hline kemampuan representasi (K. 1) & $\begin{array}{l}\text { menggunakan berbagai macam } \\
\text { representasi dalam pemecahan } \\
\text { masalah. }\end{array}$ & $\begin{array}{l}\text { siswa menggunakan } \\
\text { representasi dalam bentuk } \\
\text { tabel untuk memecahkan } \\
\text { masalah }\end{array}$ \\
\hline $\begin{array}{l}\text { kemampuan menggunakan } \\
\text { bahasa dan operasi simbolis, } \\
\text { formal dan teknis (K. 2) }\end{array}$ & $\begin{array}{l}\text { menggunakan bentuk formal } \\
\text { berdasarkan definisi dan aturan } \\
\text { matematika }\end{array}$ & $\begin{array}{l}\text { siswa manganan } \\
\text { variabel untuk memisalkan } \\
\text { nama-nama pesilat }\end{array}$ \\
\hline
\end{tabular}

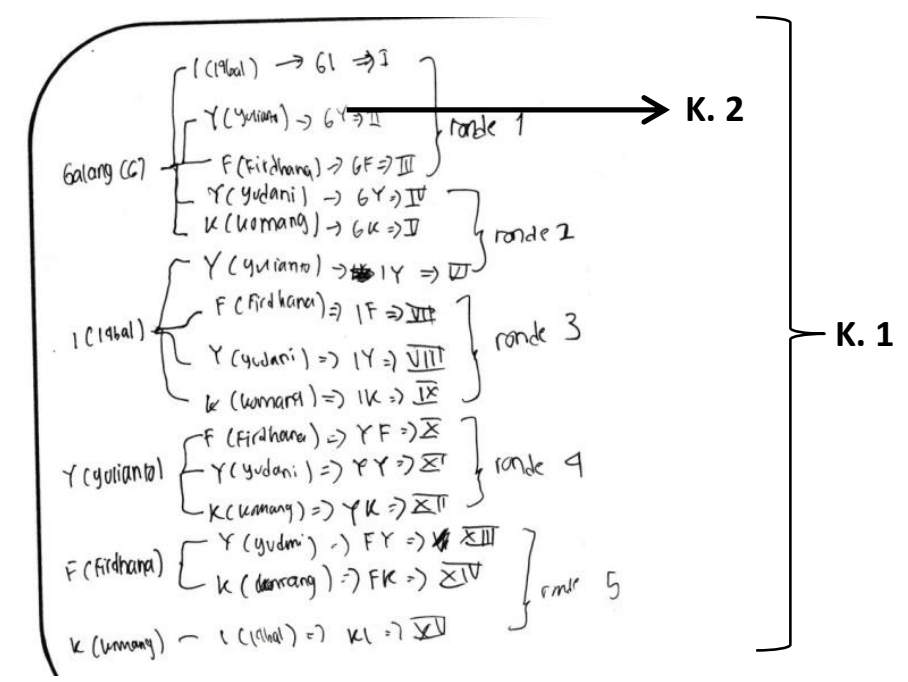

Gambar 3. Jawaban Siswa Strategi 2

Selain itu pada gambar 3 dapat dilihat terdapat siswa yang mempunyai strategi lain dengan menggunakan diagram pohon. Dari hasil pengerjaan memunculkan kemampuan representasi (K. 1) dan kemampuan menggunakan bahasa dan operasi simbolis, formal dan teknis (K. 2). Adapun penjelasan deskriptor pada kemampuan tersebut dapat dilihat pada tabel 5.

Tabel 5. Kemampuan yang Muncul

\begin{tabular}{|l|l|l|}
\hline Kemampuan & Deskriptor & Jawaban Siswa \\
\hline kemampuan representasi (K. 1) & $\begin{array}{l}\text { menggunakan berbagai macam } \\
\text { representasi dalam pemecahan } \\
\text { masalah. }\end{array}$ & $\begin{array}{l}\text { karena siswa menggunakan } \\
\text { representasi dalam bentuk } \\
\text { diagram untuk } \\
\text { memecahkan masalah }\end{array}$ \\
\hline $\begin{array}{l}\text { kemampuan menggunakan } \\
\text { bahasa dan operasi simbolis, } \\
\text { formal dan teknis (K. 2) }\end{array}$ & $\begin{array}{l}\text { menggunakan bentuk formal } \\
\text { berdasarkan definisi dan aturan } \\
\text { matematika }\end{array}$ & $\begin{array}{l}\text { karena siswa menggunakan } \\
\text { variabel untuk memisalkan } \\
\text { nama-nama pesilat misal Y } \\
\text { untuk Yudani }\end{array}$ \\
\hline
\end{tabular}


Dari penelitian telah dihasilkan soal matematika tipe PISA yang menggunakan konteks pencak silat yang valid dan praktis serta memiliki efek potensial terhadap kemampuan literasi matematis. Untuk kevalidan terlihat dari hasil penilaian expert (pakar) dari ranah konten, konstruk dan bahasa ketika tahap expert reviews. Kemudian kevalidan didapatkan juga dari komentar siswa ketika pada tahap one-to-one terhadap kejelasan dari soal (Zulkardi, 2003). Kejelasan dari soal tersebut yaitu dari keterbacaan dari soal, kejelasan dari gambar.

Kepraktisan dari soal terlihat pada tahap small group, yaitu siswa sudah dapat mengerti dengan baik mengenai soal (Riyanto et al., 2018; Zulkardi, 2003, 2006). Hal ini terlihat dari siswa sudah memahami dengan baik dari bahasa soal maupun pertanyaan soal. Kemudian soal yang dikembangkan juga memiliki efek potensial terhadap kemampuan literasi matematis siswa. Kemampuan literasi matematis yang muncul adalah kemampuan representasi dan kemampuan menggunakan bahasa dan operasi simbolis, formal dan teknis. Hal ini terlihat dari strategi siswa dalam mengerjakan soal.

\section{KESIMPULAN}

Telah dihasilkan soal matematika tipe PISA yang menggunakan konteks pencak silat yang valid dan praktis serta memiliki efek potensial terhadap kemampuan literasi matematis. Untuk kevalidan terlihat dari hasil penilaian expert dari ranah konten, konstruk dan bahasa ketika tahap expert reviews, serta kevalidan didapatkan dari komentar siswa ketika one-to-one terhadap kejelasan dari soal. Tahap small group terlihat kepraktisan dari soal, yaitu siswa sudah dapat mengerti dengan baik mengenai soal. Kemudian soal yang dikembangkan juga memiliki efek potensial terhadap kemampuan literasi matematis siswa. Kemampuan literasi matematis yang muncul adalah kemampuan representasi dan kemampuan menggunakan bahasa dan operasi simbolis, formal dan teknis. Berdasarkan hasil penelitian dan pembahasan disarankan bagi guru maupun siswa agar dapat melatih mengerjakan soal matematika dengan lebih baik terutama soal PISA.

\section{UCAPAN TERIMA KASIH}

Terima kasih kepada Ibu Eriga, M.Pd. selaku guru matematika di SMA N 1 Palembang yang telah membantu dalam penelitian serta seluruh pihak sekolah yang telah mengizinkan peneliti untuk melakukan penelitian di sekolah.

\section{REFERENSI}

Andita, S., Septy, L., Nizar, H., \& Nery, R. S. (2020). Validitas Soal Matematika Tipe PISA Konteks Covid-19. Jurnal Of Education in Mathematics, Science, and Technology, 3(2), 89-100. http://jemst.ftk.uinjambi.ac.id/index.php/jemst/article/view/38

Astuti, P. (2018). Kemampuan Literasi Matematika dan Kemampuan Berpikir Tingkat Tinggi. Prisma, Prosiding Seminar Nasional Matematika.

Dasaprawira, M. N., Zulkardi, \& Susanti, E. (2019). Developing mathematics questions of Pisa type 
using Bangka context. Journal on Mathematics Education. https://doi.org/10.22342/jme.10.2.5366.303-314

Hasanah, U., Wardono, W., \& Kartono, K. (2016). Keefektifan Pembelajaran Murder Berpendekatan PMRI dengan Asesmen Kinerja pada Pencapaian Kemampuan Literasi Matematika SMP Serupa PISA. Unnes Journal of Mathematics Education, 5(2), 101-108. https://doi.org/10.15294/ujme.v5i2.11404

Jannah, R. D., Putri, R. I. I., \& Zulkardi. (2019). Soft tennis and volleyball contexts in asian games for pisa-like mathematics problems. Journal on Mathematics Education. https://doi.org/10.22342/jme.10.1.5248.157-170

Maharani, L., Putri, R. I. I., \& Hartono, Y. (2019). Aquatic in Asian games: Context of pisa-like mathematics problem. Journal on Mathematics Education. https://doi.org/10.22342/jme.10.3.5252.459-470

Muhajir. (2016). Pendidikan Jasmani Olahraga dan Kesehatan Edisi Revisi 2016 (Balitbang (ed.)). Kemdikbud.

Nizar, H., Putri, R. I. I., \& Zulkardi. (2018a). Developing pisa-like mathematics problem using the 2018 Asian Games football and table tennis context. Journal on Mathematics Education. https://doi.org/10.22342/jme.9.2.5246.183-194

Nizar, H., Putri, R., \& Zulkardi. (2018b). PISA-like mathematics problem with karate context in Asian Games. Journal of Physics: Conference Series. https://doi.org/10.1088/1742-6596/1088/1/012063

Novita, R., Zulkardi, \& Hartono, Y. (2012). Exploring primary student's problem-solving ability by doing tasks like PISA's question. Journal on Mathematics Education. https://doi.org/10.22342/jme.3.2.571.133-150

OECD. (2019). PISA 2018 Assessment and Analytical Framework, PISA, OECD Publishing,. In Pisa 2018.

Riyanto, B., Zulkardi, Putri, R. I. I., \& Darmawijoyo. (2018). Mathematical modeling in realistic mathematics education. Journal of Physics: Conference Series. https://doi.org/10.1088/1742$6596 / 943 / 1 / 012049$

Stacey, K. (2010). Mathematical and scientific literacy around the world. Journal of Science and Mathematics Education in Southeast Asia.

Tessmer, M. (1993). Planning and conducting formative evaluations: Improving the quality of education and training. In Planning and Conducting Formative Evaluations.

Widjaja, W. (2013). The Used of Contextual Problems Support Mathematical Learning. Journal on Mathematics Education, 4(2), 151-159. http://dx.doi.org/10.22342/jme.4.2.413.151-159

Wu, M. (2011). Using PISA and TIMSS Mathematics assessments to identify the relative strengths of students in Western and Asian countries. Journal of Research in Education Sciences. https://doi.org/10.3966/2073753X2011035601003

Yansen, D., Putri, R. I. I., Zulkardi, \& Fatimah, S. (2019). Developing pisa-like mathematics problems 
on uncertainty and data using asian games football context. Journal on Mathematics Education. https://doi.org/10.22342/jme.10.1.5249.37-46

Zulkardi. (2003). DEVELOPING A LEARNING ENVIRONMENT ON REALISTIC MATHEMATICS EDUCATION FOR INDONESIAN STUDENT TEACHERS. Thesis University of Twente, Enschede. - With Refs. - With Summary in Ducth ISBN 9036518458 Subject.

Zulkardi. (2006). Formative Evaluation: What, why, when, and how. http://www.oocities.org/zulkardi/books.html.

Zulkardi. (2010). PISA, KTPS, and UN. Proceeding KNM XV, 53-54. https://repository.unsri.ac.id/6327/1/053-054_Zulkardi-KNM-Manado-2010.pdf 